\title{
Metody redukcji hałasu w świetle wymagań środowiskowych oraz uregulowań prawnych
}

\author{
Tomasz LEŚNIAK ${ }^{1)}$, Arkadiusz KUSTRA ${ }^{2)}$
}

\footnotetext{
1) mgr inż.; Szkoła Doktorska Akademii Górniczo-Hutniczej, Kraków, Polska

2) dr hab. inż., prof. uczelni; Akademia Górniczo-Hutnicza, Wydział Górnictwa i Geoinżynierii, Kraków, Polska, email: kustra@agh.edu.pl
}

http://doi.org/10.29227/IM-2020-01-85

Submission date: 27-02-2020 | Review date: 22-04-2020

Abstrakt
Głównym celem publikacji było przedstawienie metod redukcji hałasu w świetle decyzji środowiskowych, prawnych oraz ekonomicz-
nych. Realizując cel wykorzystano badania literatury. W ramach rozważań teoretycznych skupiono się na zdefiniowaniu problemu
hałasu przemysłowego jako jednego z głównych rodzajów hałasu. Przedstawiono w jakim stopniu hałas wpływa zarówno na środowi-
sko wewnętrzne przedsiębiorstwa jak iśrodowisko naturalne, zakłócając naturalny stan zwany ciszą. Wyszczególniono najważniejsze
uregulowania prawne wostaci dyrektyw, ustaw oraz rozporządzeń, które maja na celu unormowanie warunków pracy iśrodowiska.
W dalszej części publikacji przedstawiono i pogrupowano metody redukcji hałasu, klasyfikując tym samym metody redukcji do
konkretnych problemów przemysłowych. W ostatniej części publikacji skupiono się na ekonomicznym wymiarze problemu hałasu.
Wyodrębniono obszary odpowiedzialne za generowanie kosztów w związku z utrzymywaniem się wysokiego poziomu hałasu oraz
kosztami związanymi z inwestycja w metody redukcji hałasu.
Niniejsza publikacja stanowi podstawę do dalszych rozważań na temat ekonomicznej zasadności inwestowania w metody walki
$z$ uciążliwym hałasem przemysłowym.

Słowa kluczowe: aktywna redukcja hałasu, hałas przemysłowy, opłacalność inwestycji, wymagania środowiskowe

\section{Wstęp}

Wiedza na temat chorób zawodowych rozwija się z roku na rok. Coraz większy nacisk kładzie się na kwestie bezpieczeństwa oraz komfortu pracy. Czynniki te stanowią o efektywności pracowników, którzy mając poczucie komfortowych warunków, są w stanie skupić się na pracy oraz wykonywać ją zgodnie z założeniami. Kwestie bezpieczeństwa oraz komfortu pracy reguluje Centralny Instytut Ochrony Pracy (CIOP), który kategoryzuje zagrożenia i dopasowuje je do danej grupy zawodowej, tworząc tak zwane karty charakterystyk zagrożeń zawodowych.

Rozpatrując przypadek pracowników przemysłowych, którzy związani są z wydobyciem lub produkcją dóbr, należy zwrócić szczególną uwagę na powtarzające się czynniki środowiska pracy, które związane są z wykonywaną profesją. Jednym z czynników fizycznych, który dotyka coraz większą liczbę fabryk jest nadmierny hałas, który w konsekwencji może prowadzić do trwałego uszkodzenia słuchu. Mimo coraz skuteczniejszych środków prewencji przedsiębiorstwa borykają się z wysokimi karami za nieprzestrzeganie norm hałasu i drgań. Dodatkowo poszkodowani pracownicy wstępują na drogę sądową i wygrywają wysokie odszkodowania z tytułu narażenia zdrowia w miejscu pracy. Niesie to za sobą również negatywne skutki wizerunkowe.

Innym aspektem dotyczącym ekonomicznego obszaru działania przedsiębiorstw jest spadek wydajności w miejscu pracy. Maszyny, które na co dzień uciążliwie działają na ludzką pracę w dłuższym okresie czasu powodują, że pracownicy stają się zdecydowanie bardziej rozdrażnieni oraz mniej skupieni na wykonywanych czynnościach co w konsekwencji powoduje bezpośrednie zagrożenia zdrowia. Spadek wydajności wiąże się z dodatkowymi kosztami związanymi z niskimi nor- mami pracy czy utrudnieniem wprowadzenia trzecich zmian do systemu płacowego.

Warto również wspomnieć o aspekcie wpływu hałasu przemysłowego na otoczenie przedsiębiorstwa.

W publikacji przedstawiono metody redukcji hałasu, które ze względu na zakres częstotliwości oraz charakter dźwięku podzielono na dwa główne rodzaje. Zarysowano również tło wymagań środowiskowych, zarówno dotyczących środowiska pracy pracownika jak i działania hałasu przemysłowego na środowisko naturalne.

\section{Hałas przemysłowy}

Hałas przemysłowy zależy w dużym stopniu od procesu technologicznego, stosowanych maszyn, poziomu automatyzacji oraz mechanizacji. Stąd też charakterystyka hałasu różni się zakresem częstotliwości oraz kierunkowością jego źródła. Ze względu na zakres częstotliwości możemy wyróżnić infradźwięki, które definiowane są jako hałas, którego widmo częstotliwości zawarte jest w zakresie 1-20 Hz, hałas słyszalny, którego częstotliwości zawierają się w zakresie $20-20000 \mathrm{~Hz}$ oraz hałas ultradźwiękowy w pasmach od 20-40kHz. Problemem, który dotyka najczęściej przemysł jest hałas niskoczęstotliwościowy, obejmujący zakres od 10-250 Hz. Hałas ten wyodrębniony jest ze względu na stwierdzoną uciążliwość, potwierdzoną skargami osób narażonych na ten rodzaj hałasu (Kaczmarska, Augustyńska, 2001 CIOP). Charakterystycznym zjawiskiem dla infradźwięków i hałasu niskoczęstotliwościowego jest wzmacnianie fali determinowane rezonansem konstrukcji oraz obiektu co wpływa na percepcję tych fal u człowieka. Skutkami długotrwałego przebywania w środowisku hałasu niskoczęstotliwościowego jest zmęczenie, senność oraz obniżenie stanu czuwania, co w warunkach 
Tab. 1. Przykładowe zestawienie poziomów ciśnienia akustycznego w halach oraz kabinach obsługi dla wybranych urządzeń przemysłowych. Źródło: Kaczmarska, Augustyńska, Warszawa 2001, CIOP

Tab. 1. Example list of sound pressure levels in halls and service cabins for selected industrial devices. Source: Kaczmarska, Augustyńska, Warsaw 2001, CIOP

\begin{tabular}{|l|l|l|}
\hline \multicolumn{1}{|c|}{ Urządzenie } & \multicolumn{1}{|c|}{ Poziom ciśnienia akustycznego } & \multicolumn{1}{c|}{ Poziom dźwięku G } \\
\hline $\begin{array}{l}\text { Sprężarki tłokowe }(200-1000 \\
\text { obr/min) }\end{array}$ & $85-120 \mathrm{~dB}$ w halach & $90-116 \mathrm{~dB}$ w halach \\
Elektryczne piece łukowe $(60 \mathrm{t}$, & $75-104 \mathrm{~dB}$ w halach & $96-107 \mathrm{~dB}$ w kabinach obsługi \\
160t) & $80-108 \mathrm{db}$ w kabinach obsługi & $102-105 \mathrm{~dB}$ w kabinach obsługi \\
\hline \multirow{2}{*}{ Wentylatory przemysłowe } & $80-100 \mathrm{~dB}$ w halach & $86-110 \mathrm{~dB}$ w halach \\
& $72-91 \mathrm{~dB}$ w kabinach obsługi & $86-92 \mathrm{~dB}$ w kabinach obsługi \\
\hline Młyny młotowe $(100 \mathrm{t} / \mathrm{h}, 250 \mathrm{t} / \mathrm{h})$ & $80-100 \mathrm{~dB}$ w halach & $103-107 \mathrm{~dB}$ w halach \\
\hline
\end{tabular}

przemysłowych jest nieakceptowalne. Najczęstsze źródła hałasu niskoczęstotliwościowego zestawiono w tabeli 1.

Wyniki wyraźnie wskazują na wysoki poziom hałasu nie tylko na halach, ale również w kabinach, które są przeznaczone do realizacji zadań pracownika obsługi. Dodatkowo wyniki te zdecydowanie odbiegają od przyjętych norm hałasu i drgań dla stanowisk pracy.

Ramy prawne reguluje przede wszystkim Konwencja nr 148 Międzynarodowej Organizacji Pracy, która dotyczy ochrony pracowników przed zagrożeniami zawodowymi w miejscu pracy spowodowanymi zanieczyszczeniami powietrza, hałasem i wibracjami, przyjęta w Genewie dnia 20 czerwca 1977 roku a ratyfikowana w Polsce dnia 4 listopada 2004 roku. Zakłada ona skupienie się na prewencji, zapobieganiu oraz reagowaniu na nadużycia w związku z narażeniem pracowników między innymi na hałas. Nakłada ona zatem obowiązek podjęcia działań w tym obszarze, zarówno na Państwo jak i na przedsiębiorców. Rozporządzeniem Ministerstwa Gospodarki i Pracy z dnia 5 sierpnia 2005 roku dotyczącym bezpieczeństwa i higieny pracy przy pracach związanych z narażeniem na hałas lub drgania mechaniczne (Dz. U, nr 157, poz. 1318) oraz Dyrektywy Rady 89/391/EWG z dnia 12 czerwca 1989 roku w sprawie wprowadzenia środków w celu poprawy bezpieczeństwa i zdrowia pracowników w miejscu pracy i Dyrektywy Hałasowej 2003/10/WE Parlamentu Europejskiego i Rady z dnia 6 lutego 2003 wprowadzone zostały zatem wartości progów dla poziomu ekspozycji na hałas w ośmiogodzinnym wymiarze pracy, hałas ten nie może przekraczać $85 \mathrm{~dB}$, dla szczytowego poziomu dźwięku A nie może przekraczać $115 \mathrm{~dB}$, natomiast szczytowy poziom dźwięku C nie może być wyższy niż $135 \mathrm{~dB}$. (CIOP).

Redukcja hałasu odbywa się za pomocą dwóch podstawowych metod: pasywnej oraz aktywnej. Warto również zaznaczyć wagę przeprowadzenia dokładnych badań i pomiarów hałasu, aby już w fazie prototypowania rozwiązań redukujących hałas znacząco ograniczyć koszty.

\section{Hałas przemysłowy a środowisko}

Drugą stroną hałasu przemysłowego jest jego oddziaływanie na otaczające środowisko naturalne i sąsiedztwo. Jest to zjawisko coraz bardziej powszechne w otoczeniu człowieka. Wiąże się to z mocną urbanizacją i uprzemysłowieniem terenów. Hałas dotyka zarówno ludzi, którzy mieszkają w pobliżu terenów przemysłowych jak i naturalnej fauny. W przypadku ludzi problem taki tyczy się zwłaszcza pracowników kopalń, którzy mieszkają w większości w miastach, które celowo były lokowane w bliskim sąsiedztwie miejsca pracy ze względu na komfort i oszczędności.
Hałas przemysłowy jest oczywiście jednym z elementów całego zbioru rodzajów hałasu, natomiast jego specyfika wymaga specjalistycznego podejścia. Wiemy bowiem, że ten rodzaj hałasu odbierany jest przez człowieka jako uciążliwy (van Gerven, 2009). Uciążliwość hałasu jest bowiem najpowszechniejszym oraz najlepiej udokumentowanym jego skutkiem, który może powodować lęki, poczucie gniewu oraz ciągłego zmęczenia (Stansfeld, Matheson, 2003). Istnieje również zagrożenie adaptacji takiego hałasu przez człowieka. Zjawisko to zmniejsza uciążliwość, natomiast jest to tendencja wysoce niepokojąca, mogąca prowadzić do niekorzystnych skutków zdrowotnych (Laszlo, McRobie, 2012). Hałas przemysłowy wpływa bowiem na takie obszary funkcjonowania człowieka jak układ sercowo - naczyniowy, ciśnienie krwi, układ hormonalny czy też na problemy ze snem (Pawlas, 2015).

Dodatkowo hałas pochodzenia ludzkiego dotyka nie tylko człowieka, ale także całego środowiska. Zaburza bowiem ekosystem naturalny, któremu od zawsze towarzyszyło zjawisko ciszy (EEA Report No 22/2019). Cisza w ekosystemie to wartość, która w sposób naturalny jest odbierana przez faunę oraz florę. Od zawsze była wrogiem ptaków, których śpiew nasłuchiwały największe drapieżniki. Hałas pochodzenia antropogenicznego, również pochodzący z fabryk zaburzył zatem taki stan rzeczy, w którym ptaki mogą się skutecznie maskować i bronić (McClure, 2013). Zaburzenia w funkcjonowaniu środowiska naturalnego stanowią globalny problem, który regulują międzynarodowe przepisy.

W celu poprawy jakości środowiska i wspólnego funkcjonowania Unia Europejska w Dyrektywie 2002/49/WE Parlamentu Europejskiego i Rady z dnia 25 czerwca 2002 odnoszącej się do oceny i zarządzania poziomem hałasu w środowisku wyraźnie definiuje pojęcie hałasu w środowisku oraz przedstawia cele dotyczące walki z tym problemem. Jako jedną z głównych odpowiedzialności wskazuje na sporządzenie oraz gromadzenie planów strategicznych walki $\mathrm{z}$ hałasem w środowisku.

W Polsce o środowisku w sposób prawny decyduje Ustawa z dnia 27 kwietnia 2001 roku Prawo ochrony środowiska (Dz.U.2001 nr 62 poz.627) na podstawie której opublikowano Rozporządzenie Rady Ministrów z dnia 29 września 2001 roku w sprawie wysokości jednostkowych stawek kar za przekroczenie dopuszczalnego poziomu hałasu. (Dz. U. nr 120 poz. 1285). Stawki te jednak nie wywierają dostatecznej presji na przedsiębiorcach oraz podmiotach, które generują hałas na skalę masową.

Zjawisko hałasu przemysłowego ma zatem duże przełożenie na pracę osób przebywających w takich warunkach jak i ludzi oraz zwierząt, którzy narażeni są na hałas w śro- 


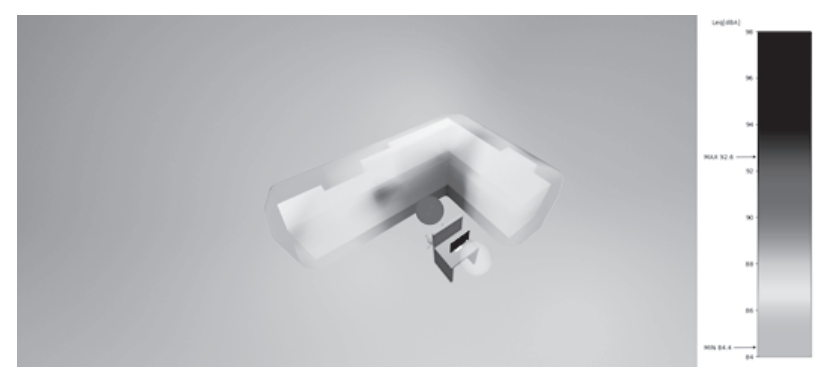

Rys. 1. Przykładowa strefa ciszy oraz wskazanie źródeł hałasu wokół maszyny. Źródło: opracowanie własne

Fig. 1. Example of a quiet zone and indication of noise sources around the machine. Source: own study

dowisku naturalnym. Jednak w wyniku coraz dokładniejszej wiedzy na temat zjawisk akustycznych pojawiły się w nauce metody redukcji hałasu zarówno słyszalnego jak i niskoczęstotliwościowego.

\section{Pasywne metody redukcji hałasu}

Metoda pasywna, zwana bierną wykorzystuje wszelkiego rodzaju izolacje, pochłaniacze oraz rozpraszacze dźwięku. Wymienione materiały stosowane są dla hałasu o wyższym paśmie częstotliwości, które stanowią słyszalny problem hal przemysłowych. Mają one na celu ochronę przeciwdźwiękową zarówno elementów konstrukcji jak zabezpieczenie urządzeń, instalacji oraz przede wszystkim słuchu pracowników.

Powołując się na badania literaturowe hałas, który wytwarzany jest $\mathrm{w}$ środku fabryki możemy niwelować za pomocą sprawdzonych elementów ochrony, takich jak amortyzacja drgań maszyny, izolowanie przejść i podwieszeń przewodów, stosowanie obudowy oraz ekranów dźwiękochłonnych. Dodatkowo warto wspomnieć o elementach ochrony, które w bezpośredni sposób przekładają się na konstrukcje budynku. Wyróżniono wówczas takie elementy ochrony jak wydzielanie z konstrukcji budynku pomieszczeń w których znajduje się źródło hałasu i drgań oraz izolowanie samych fundamentów pod kątem źródeł drgań.

Za pomocą wymienionych elementów skutecznej ochrony przeciwdźwiękowej wykonywane są adaptacje akustyczne hal przemysłowych. Mają one na celu zwiększenie chłonności akustycznej oraz organizowanie środowiska pracy w taki sposób, aby maszyny nie tworzyły jeszcze większego źródła hałasu. Dodatkowo w ramach prac adaptacyjnych należy zwrócić szczególną uwagę na kształt hali produkcyjnej, która w wielu przypadkach powoduje niekorzystne zjawiska akustyczne. (Engel, 2001, PWN).

Inną z biernych metod są obudowy dźwiękochłonne, które mają za zadanie chronić i ograniczyć przenoszenie energii wibroakustycznej od źródła. Sam proces zaczyna się od fazy projektowania obudów. W tym etapie określane są najważniejsze warunki oraz wymagania, które musi spełnić obudowa. Tyczy się to między innymi izolacyjności akustycznej, wymogów bezpieczeństwa pożarowego, wybuchowego oraz odporności na uszkodzenia mechaniczne. W praktyce obudowy muszą również nie ingerować w pracę użytkownika maszyny, co za tym idzie jest to metoda nie w pełni efektywna. Zabudowanie maszyny wiąże się z dyskomfortem pracy oraz utrudnieniami w produkcji. Nieprawidłowo zaprojektowana obudowa może skutkować innymi zagrożeniami, stąd też w przemyśle odchodzi się od stosowania tego rodzaju ochrony przed hałasem.
Częściej stosowaną metodą są kabiny dźwiękoszczelne, które izolują pracownika od źródła hałasu. Są one stosowane dla hal produkcyjnych w której pracownicy mogą monitorować i nadzorować proces produkcji i tylko w nielicznych przypadkach opuszczają stanowisko monitoringu. Podobnie jak w poprzedniej metodzie istota leży po stronie projektu kabiny, natomiast jest to dużo bardziej elastyczna forma ochrony pracownika przed uciążliwym hałasem. Istotą skuteczności kabiny dźwiękoszczelnej jest izolacyjność akustyczna. Jest ona zależna przede wszystkim od różnicy między równoważnym poziomem dźwięku $\mathrm{w}$ hali a poziomem równoważnym dopuszczalnym w kabinie (Engel, $2001 \mathrm{PWN}$ ).

Innym rozwiązaniem, które skutecznie stosowane jest $\mathrm{w}$ walce $\mathrm{z}$ hałasem przemysłowym są ekrany akustyczne. Ekrany stanowią naturalną przeszkodę dla fali akustycznej. Ekrany akustyczne mają swoje zastosowanie w układzie źródła hałasu, ekranu oraz człowieka, który pracuje w obszarze o zwiększonym ryzyku utraty słuchu. Ekranowanie oparte jest na zjawisku ugięcia fali, które opierając się na zasadzie Huygensa mówiącej o tym, że „wszystkie punkty czoła fali można uznać za źródła nowych fal akustycznych" ogranicza skuteczność ekranów w ich krawędziach i skutkuje zmniejszeniem efektywności cienia akustycznego.

Metody pasywnej redukcji hałasu zwalczają hałas o wyższych częstotliwościach. Skutkują one realnym obniżeniem poziomu hałasu od kilku do kilkunastu decybeli w wyznaczonych pasmach częstotliwości.

\section{Aktywne metody redukcji hałasu}

Rozwiązanie problemu hałasu niskoczęstotliwościowego leży w zastosowaniu metod aktywnych. Skupiając się na zagadnieniu hałasu przemysłowego warto wspomnieć o początkach badań nad aktywną redukcją hałasu, które datowane są na 1892 rok. Pojawiły się wówczas prace J.I. Thorncrofta oraz A.F.Yarrowa dotyczące metod aktywnej redukcji drgań środków transportu oraz maszyn i urządzeń. Rok 1920 przynosi patent S.Motora dotyczący układu redukcji drgań. W latach trzydziestych P.Lueg złoży patent dotyczący układu akustycznego natomiast H.Nyquist sformułował matematyczną teorię stabilnych sprzężonych zwrotnie procesów drganiowych (Engel, Makarewicz, 2001 CIOP). Kolejny rozkwit metod aktywnej redukcji hałasu przypadł na lata siedemdziesiąte XX wieku. Wówczas badania G.B.Chaplina oraz G.E.Warnaki doprowadziły do dzisiaj już znanej istoty skuteczności aktywnych metod redukcji hałasu, które opierają się na odwróceniu oraz przesunięciu fazy wytworzonych fal dźwiękowych.

Pierwsze systemy aktywnej redukcji hałasu zostały zastosowane w rozwiązaniach wojskowych, wytłumiania helikop- 


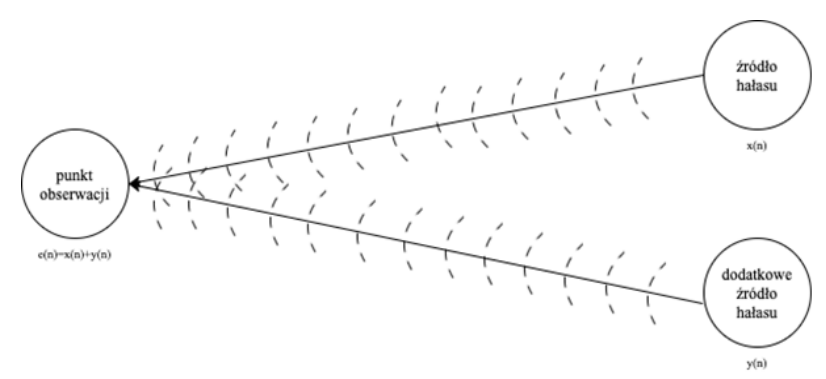

Rys. 2. Zasada kompensacji dźwięku. Źródło: Górski, Jurkiewicz 2014

Fig. 2. Sound compensation principle. Source: Górski, Jurkiewicz 2014

terów oraz łodzi podwodnych. Dziś nauka ta zdecydowanie rozwinęła się w kierunku poprawy warunków pracy ludzi w przemyśle. Hałas maszyn oraz poszczególnych części silnika maszyny jest istotnie tłumiony. Powstają wówczas tak zwane strefy ciszy, w których pracownik może przebywać i wykonywać swoją pracę $\mathrm{z}$ mniejszym ryzykiem utraty słuchu. Przykładową strefę ciszy wokół maszyny przedstawiono na rysunku 1.

Podstawą działania systemów redukcji hałasu jest zasada kompensacji dźwięku, która polega na zastosowaniu dodatkowych źródeł energii akustycznej i odpowiednim kształtowaniu rozkładu parametrów pola akustycznego w otoczeniu źródła (Górski, Jurkiewicz AGH 2004). Zasadę kompensacji dźwięku zaprezentowano na rysunku 2. W całym procesie brane są pod uwagę dwa główne źródła sygnałów: emitowane przez źródło samego hałasu oraz emitowane dodatkowo przez inne źródło dźwięku, które ma na celu kompensację hałasu. Kompensacja ta następuje poprzez nakładanie się sygnałów w punkcie obserwacyjnym, gdzie powstaje sygnał wynikowy o mniejszej amplitudzie niż sygnał kompensowany, pochodzący ze źródła hałasu.

Sam system aktywnej redukcji hałasu działa w wąskim paśmie częstotliwości. Implikuje to konieczność określania źródeł hałasu, jego przyczyn oraz precyzyjną definicję częstotliwości. Implikacja ta jednak daje możliwość redukowania tylko i wyłącznie wybranych elementów maszyn, co stanowi pole do optymalizacji wdrożeń systemów. Istotą zatem jest skupienie się na wybranych częstotliwościach, które powodują redukcję hałasu najbardziej uciążliwych dla pracownika częstotliwości. Dodatkowe zastosowanie metod pasywnych do tłumienia częstotliwości słyszalnych daje możliwość kompleksowego ujęcia problemu hałasu przemysłowego. Schemat działania aktywnej redukcji hałasu przedstawiono na rysunku 3.

Maszyna, która jest źródłem dźwięku wytwarza hałas o określonej częstotliwości. Hałas ten pochodzi w dużej mierze z silnika maszyny. Mikrofon, który ustawiony jest kierunkowo w stosunku do źródła zbiera sygnał i przesyła go do jednostki sterującej. W niej, za pomocą algorytmów sztucznej inteligencji jest on przetwarzany. Przetwarzanie sygnału polega na przesunięciu oraz odwróceniu fazy sygnału. Tak przetworzony sygnał wysyłany jest do głośnika, czyli drugiego źródła dźwięku. Głośnik emituje odwrócony i przesunięty w fazie sygnał, redukując hałas w częstotliwościach od 50-500 $\mathrm{Hz}$, czyli w zakresie hałasu niskoczęstotliwościowego.

Redukcja hałasu metodą aktywną daje możliwość wykluczenia szeregów zabudowań maszyny i skupienia się na określonych pasmach częstotliwości, które z punktu widzenia zdrowotnego są szkodliwe i uciążliwe. Takie rozwiązanie sta- nowi ekonomiczną alternatywę dla kosztownych i nie zawsze efektywnych rozwiązań pasywnych.

\section{Ekonomiczny aspekt zastosowania metod redukcji hałasu}

W myśl Rozporządzenia Ministra Zdrowia w sprawie badań i pomiarów czynników szkodliwych w środowisku pracy należy zdawać sobie sprawę z faktu, iż przedsiębiorca musi zapewnić pracownikowi warunki, w których ekspozycja na hałas przemysłowy nie będzie przekraczała $85 \mathrm{~dB}$ przy ośmiogodzinnym czasie pracy. $Z$ tego względu rozwiązaniem ostatecznym są proponowane najczęściej w środowisku przemysłowym nauszniki oraz słuchawki redukujące hałas. Są to doraźne metody, które nie wpływają na otoczenie, w którym pracownik przebywa oraz nie redukują wszystkich problemów. Dodatkowo Rozporządzenie z dnia 2 lutego 2011 roku wymusza na przedsiębiorcach umieszczanie aktualnych wyników badań i pomiarów w pobliżu stanowiska pracy.

W związku z takim podejściem do sytuacji przedsiębiorcy są zobligowani do stosowania metod zarówno pasywnych jak i aktywnych, które poprawią warunki pracy w sposób trwały. Dodatkowo przedsiębiorcy muszą przedstawić plan długoterminowy zmniejszający ryzyko zawodowe na stanowisku pracy. Stąd też aktualna ocena ryzyka zawodowego musi zawierać takie elementy jak (Dz.U. 2011 nr 33 poz.166):

- Rodzaj czynników oraz ich właściwości;

- Procesy technologiczne i ich parametry;

- Wyposażenie techniczne;

- Środki ochrony zbiorowej;

- Organizacja pracy i sposób jej wykonywania;

- Rzeczywisty czas narażenia na oddziaływanie czynników szkodliwych dla zdrowia.

Przedstawienie długoterminowej strategii działania wymaga przygotowania się zarówno pod kątem technicznym jak i ekonomicznym. W wypadku przedsiębiorstw przemysłowych należy przede wszystkim zwrócić uwagę na dwa obszary - narażenia na hałas pracowników oraz otoczenia. Działając w sposób kompleksowy należy zapewnić optymalny poziom redukcji hałasu przy ekonomicznie uzasadnionych wydatkach inwestycyjnych. Stąd też tak kluczową rolę w procesie decyzyjnym odgrywają wstępne pomiary oraz badania kierunkowości i źródła fali akustycznej. W ujęciu strategicznym ograniczają one koszty inwestycji w długim okresie czasu. Dokładna identyfikacja problemu, uwzględniająca różne częstotliwości i ich wpływ na charakter hałasu, daje możliwość zastosowania optymalnych metod redukcji hałasu. Zastosowanie metod pasywnych oferujących wygłuszenie wysokoczęstotliwościowych tonów daje możliwości redukcji hałasu do poziomów 


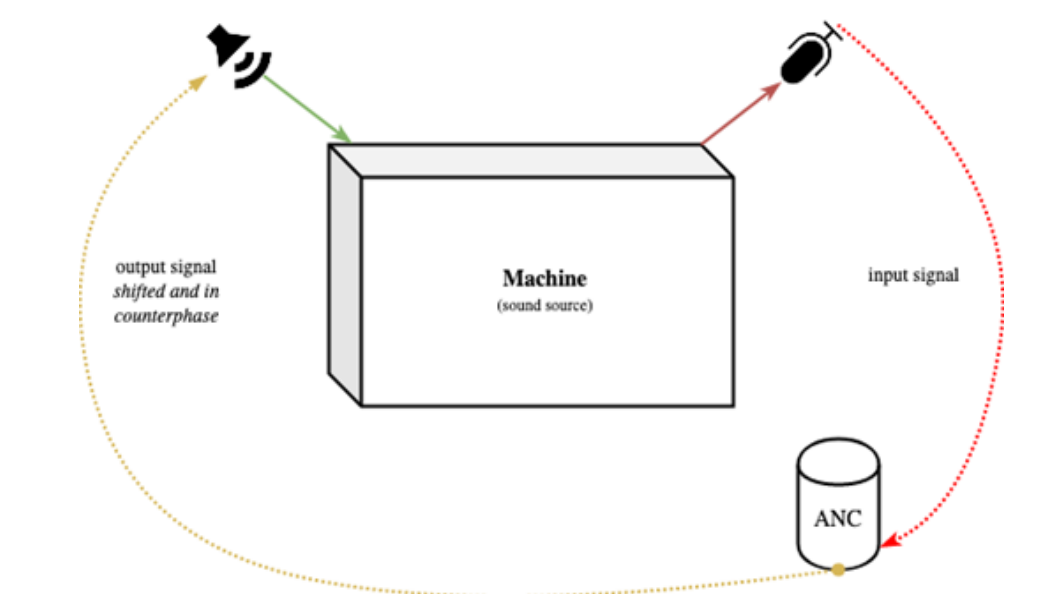

Rys. 3. Schematyczne działanie systemu aktywnej redukcji hałasu. Źródło: opracowanie własne

Fig. 3. Schematic operation of the active noise reduction system. Source: own study

granicznych. Dodatkowo metody pasywne umożliwiają walkę $\mathrm{z}$ hałasem przemysłowym w środowisku, realnie zmniejszając poziom decybeli, które docierają do niego. Należy jednak zwrócić uwagę na długotrwałą ekspozycję pracownika i częstotliwości niskotonowe, określane jako najbardziej uciążliwe. Redukcja hałasu w sposób aktywny daje zatem możliwość realnego odciążenia słuchu i percepcji pracowników jak i pobliskich mieszkańców terenów przemysłowych.

Opracowanie finansowej strategii długoterminowej należy zatem oprzeć o takie elementy jak budżet wdrożenia i utrzymania metod aktywnych oraz pasywnych, budżet prowadzenia badań oraz pomiarów dokonywanych na stanowiskach pracy oraz redukcję kosztów alternatywnych w postaci kar za niespełnianie wymogów środowiskowych oraz kar nałożonych $\mathrm{w}$ sprawach sądowych. W ramach strategii finansowej należy rozpocząć pracę nad elastycznym modelem finansowym dla inwestycji dotyczących ochrony środowiska pracy jak i środowiska naturalnego, którego naturalnym zagrożeniem w dzisiejszych czasach jest hałas.

W wypadku firm przemysłowych, fabryk, dodatkowym aspektem ekonomicznym, który jest brany pod uwagę w decyzji o inwestycji w strategiczne metody redukcji hałasu jest możliwość podjęcia dodatkowych zmian, które mogą dać możliwość zwiększonej produkcji. Ograniczenia spowodowane nadmiernym hałasem powodują dodatkowe koszty alternatywne $\mathrm{w}$ postaci limitu zmianowości pracy. Limit ten może powodować niewykorzystywanie zasobów firmy w stu procentach.

Szereg kosztów alternatywnych, kar oraz nieprzyjemności prawnych, które może wywołać brak reakcji na zagrożeniem hałasem przemysłowym determinuje pracodawców do analizy rynku systemów redukcji hałasu. Przedsiębiorcy muszą brać pod uwagę następujące elementy: koszt wstępnych pomiarów poziomu hałasu, koszt pomiarów kierunkowości oraz źródeł dźwięku, koszt projektu zabudowań, w przypadku stosowania metod pasywnych, koszt wdrożenia oraz zakupu urządzeń przystosowanych i dopasowanych do danych stanowisk pracy, koszty utrzymania systemu, jego obsługi oraz aktualizacji.

Dzisiejsze modele biznesowe idą w kierunku wydłużania łańcucha wartości. Wykorzystują to przedsiębiorstwa, które znajdując niszę na rynku związanym z redukcją hałasu oferują kompleksowe rozwiązania, będące odpowiedzią na zale- cenia i rozporządzenia europejskie. Korzystają również firmy borykające się z problemem hałasu. Poprzez podejmowanie zrównoważonych i odpowiedzialnych decyzji są w stanie zapewnić bezpieczeństwo i komfort pracy oraz zmniejszyć skutki emisji hałasu do środowiska, przez co kwestie ekonomiczne jak i wizerunkowe ulegną znacznej poprawie.

\section{Podsumowanie}

Głównym celem publikacji było zbadanie problemu hałasu, który coraz mocniej dotyka przedsiębiorstwa przemysłowe. Wpływ hałasu zaczyna być widoczny dopiero po dłuższym okresie czasu, natomiast samo zjawisko jest obecnie powszechne i rozpatrywane w kategorii uciążliwego problemu jak i zagrożenia zdrowia. Hałas podzielono zatem na trzy główne kategorie:

1. Infradźwięki, których zakres częstotliwości wynosi od 1-20 Hz.

2. Hałas słyszalny, którego zakres częstotliwości wynosi od 20-20 $000 \mathrm{~Hz}$.

3. Ultradźwięki, których zakres częstotliwości wynosi od $20000-40000 \mathrm{~Hz}$.

Dodatkowo zdefiniowano obszar hałasu niskoczęstotliwościowego (10-250 Hz), który stanowi o problemie w przedsiębiorstwach przemysłowych. Podzielono hałas przemysłowy ze względu na obszar działania, na hałas wewnątrz fabryki oraz hałas wychodzący do środowiska.

W dalszej części publikacji skupiono się na skutkach hałasu, który dotyka środowiska i wyodrębniono skutki w kilku kluczowych obszarach.

1. Skutki zdrowotne, takie jak problemy z układem sercowo-naczyniowym, podwyższonym ciśnieniem krwi czy problemami z koncentracją oraz snem.

2. Skutki środowiskowe, takie jak zaburzenie ekosystemu naturalnego i naruszenie zjawiska ciszy.

Przybliżono również uregulowania prawne, które nakładają obowiązki planistyczne oraz sprawozdawcze na członków Unii Europejskiej. Dodatkowo zapoznano się z obowiązującymi stawkami za przekroczenia hałasu w przestrzeni publicznej.

Metody redukcji hałasu podzielono na dwie główne kategorie: 
1. Pasywne metody redukcji hałasu, w których wykorzystywane są izolacje, pochłaniacze oraz rozpraszacze dźwięku. Metodę tę stosuje się do redukcji hałasu o wyższych poziomach częstotliwości, stanowiących słyszalną część problemu hałasu.

2. Aktywne metody redukcji hałasu, które wykorzystując zjawisko kompensacji dźwięku idealnie nadają się do walki z niższymi pasmami częstotliwości. Metody te bardzo dobrze skutkują $\mathrm{w}$ walce $\mathrm{z}$ hałasem niskoczęstotliwościowym, tożsamym $\mathrm{z}$ hałasem przemysłowym.

Metody redukcji hałasu to możliwe inwestycje dla firm, które taki problem mają. Inwestycje, które należy opisać w elastycznym modelu finansowym. Znaleziono zatem obszary, które należy uwzględnić $\mathrm{w}$ takim modelu. Są nimi takie elementy jak:

1. Koszty pomiarów ponoszone jeszcze przed właściwym wdrożeniem systemów redukcji, umożliwiające zdiagnozowanie skali występującego problemu.

2. Koszty badań kierunkowości oraz źródeł dźwięku, pozwalające na detekcję konkretnego źródła problemu oraz możliwości jego eskalacji.
3. Koszty projektu zabudowań, w przypadku zastosowań metod pasywnych. Projekt pozwala na dopasowanie przestrzeni i powierzchni w sposób spersonalizowany dla firmy.

4. Koszty zakupu oraz wdrożenia urządzeń specjalizujących się w aktywnej redukcji hałasu.

5. Koszty obsługi oraz aktualizacji systemu.

Elementy te należy zestawić z kosztami alternatywnymi, takimi jak niemożliwość posłania pracowników na dodatkowe zmiany, koszty procesów w przypadku uszczerbku na słuchu czy też innych kar dotyczących nieprzestrzegania przepisów dotyczących hałasu.

Wszystkie wymienione obszary należy uwzględniać w przypadku tworzenia modelu finansowego inwestycji w długim okresie czasu. Przedsiębiorstwa przemysłowe, które $\mathrm{w}$ odpowiednim czasie wygrają walkę $\mathrm{z}$ hałasem przemysłowym będą w stanie nie tylko zadbać o zdrowie swoich pracowników, spokojniejsze życie otoczenia, ale również usprawnić procesy środowiskowe oraz dostosować politykę swojej firmy do coraz mocniejszych restrykcji w kierunku walki z zanieczyszczeniami środowiska, do których w coraz większej mierze zalicza się hałas. 


\section{Literatura - References}

1. Engel Z.: „Ochrona środowiska przed drganiami i hałasem”, Wydawnictwo Naukowe PWN, wydanie drugie poprawione i uaktualnione, Warszawa, 2001, ISBN 83-01-13537-9

2. Engel Z., Makarewicz G., Morzyński L., . Zawieska W. M: "Metody aktywne redukcji hałasu", CIOP, Warszawa, 2001, ISBN 83-88703-62-5

3. Górski P. : Wybrane zagadnienia układów redukcji drgań i hałasu, Katedra Automatyzacji Procesów Akademia Górniczo-Hutnicza, 2014, 978-83-64755-02-6

4. Dyrektywa 2002/49/WE Parlamentu Europejskiego i Rady z dnia 25 czerwca 2002 odnosząca się do oceny i zarządzania poziomem hałasu w środowisku.

5. Dyrektywa Hałasowej 2003/10/WE Parlamentu Europejskiego i Rady z dnia 6 lutego 2003.

6. Dyrektywa Rady 89/391/EWG z dnia 12 czerwca 1989 roku w sprawie wprowadzenia środków w celu poprawy bezpieczeństwa i zdrowia pracowników w miejscu pracy.

7. European Environment Agency Report No 22/2019 „Environmental noise in Europe - 2020” Luxembourg: Publications Office of the European Union, 2020, ISBN 978-92-9480-209-5 ISSN 1977-8449 doi:10.2800/686249

8. Kaczmarska A., Augustyńska D., Engel Z., Górski P.: „Przemysłowe zabezpieczenia przed hałasem infradźwiękowym i niskoczęstotliwościowym”, CIOP, Warszawa, 2001, ISBN 83-88703-68-4

9. Konwencja nr 148 Międzynarodowej Organizacji Pracy, która dotyczy ochrony pracowników przed zagrożeniami zawodowymi w miejscu pracy spowodowanymi zanieczyszczeniami powietrza, hałasem i wibracjami, przyjęta w Genewie dnia 20 czerwca 1977.

10. Laszlo H.E., McRobie E.S., Stansfeld S.A., et al: Annoyance and other reaction measures to changes in noise exposure - A review. Science Total Environ. 2012; 435-436: 551-562

11. McClure CJW, Ware HE, Carlisle J, Kaltenecker G, Barber JR. 2013 An experimental investigation into the effects of traffic noise on distributions of birds: avoiding the phantom road. Proc R Soc B 280: 20132290.

12. Pawlas K.: „Hałas jako czynnik zanieczyszczający środowisko - aspekty medyczne”, Medycyna Środowiskowa - Environmental Medicine 2015, Vol. 18, No. 4, 49-56

13. Rozporządzenie Ministerstwa Gospodarki i Pracy z dnia 5 sierpnia 2005 roku dotyczącym bezpieczeństwa i higieny pracy przy pracach związanych z narażeniem na hałas lub drgania mechaniczne (Dz. U, nr 157, poz. 1318).

14. Rozporządzenie Ministra Zdrowia z dnia 2 lutego 2011 r. w sprawie badań i pomiarów czynników szkodliwych dla zdrowia w środowisku pracy (Dz.U. $2011 \mathrm{nr} 33$ poz. 166).

15. Rozporządzenie Rady Ministrów z dnia 29 września 2001 roku w sprawie wysokości jednostkowych stawek kar za przekroczenie dopuszczalnego poziomu hałasu. (Dz. U. nr 120 poz. 1285).

16. Stansfeld S. A., Matheson M.P.: , Noise pollution: non-auditory effects on health, British Medical Bulletin, Volume 68, Issue 1, December 2003, Pages 243-257

17. Ustawa $\mathrm{z}$ dnia 27 kwietnia 2001 roku Prawo ochrony środowiska (Dz.U.2001 nr 62 poz.627).

18. van Gerven J., Vos H., Van Boxel M.P. “Annoyance from environmental noise across the lifespan”. J. Acoust. Am. Soc. 2009

Noise Reduction Methods in the Light of Environmental Requirements and Legal Regulations

The main purpose of the scientific publication was to present noise reduction methods in the light of environmental, legal and economic decisions. To achieve this goal, literature research was used. Theoretical considerations focused on defining the problem of industrial noise as one of the main types of noise. It is presented to what extent noise affects both, the internal and natural environment, disrupting the natural condition called silence. The most important regulations were specified in the form of directives, acts and ordinances which aim at normalizing working and environmental conditions. The following section of publication presents and grouped noise reduction methods, thus classifying those methods for specific industrial problems. Last part of the publication focuses on the economic dimension of the noise problem. Areas responsible for generating costs in connection with the persistence of high noise levels and costs related to investment in noise reduction methods have been identified.

This specific publication is the basis for further considerations on the economic legitimacy of investing in methods to countermeasures disturbing, industrial noise.

Keywords: active noise reduction, industrial noise, investment profitability, environmental requirements 
The Comparison of Main Copper Sulphide Minerals Beneficiation Under Laboratory and Industrial Conditions at the KGHM......................7

Paweł KURZYDŁO, Witold PAWLOS

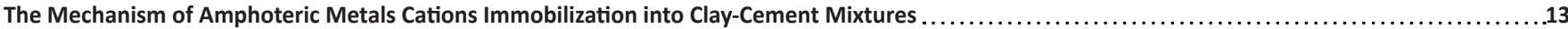

Agata STEMPKOWSKA

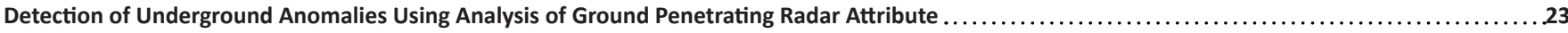

Cuong Van Anh LE, Thuan Van NGUYEN

Geodetic Activity for Compatibility of the Unit of Length of Geodetic Bases Koštice (Czech Republic) and Javoriv (Ukraine) .........................35

Igor Sevirovic TREVOGO, Jiři LECHNER, Barbara TORA, Pavel ČERNOTA, Hana STAŇKOVÁ

Kluczowe obszary due diligence $w$ procesach fuzji i przejęć w sektorze górniczym ....................................................41

Maciej MATUSZEWSKI

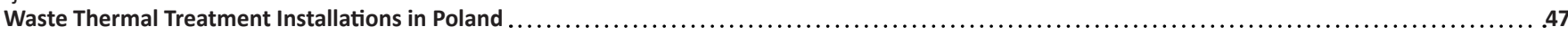

Waldemar KĘPYS, Katarzyna JASZCZURA

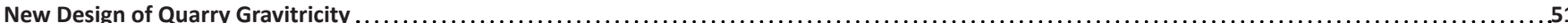

Samir REMLI, Djouama MOHAMED, Benselhoub AISSA, Rachid KHEBBAB, Nacereddine FELLOUH

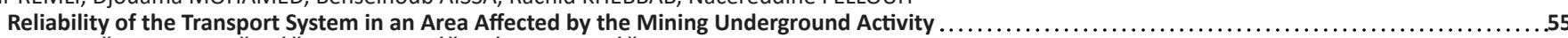

Leopold HUDEČEK, Miloslav REZÁC, Denisa CIHLÁŘOVÁ, Otto ROHÁC

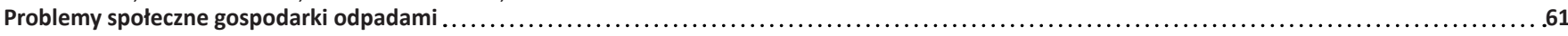

Wiktoria SOBCZYK, Anna KOWALSKA

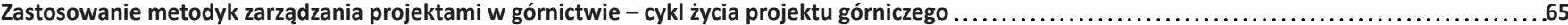

Andrzej KACPERSKI

Analiza wpływu komponentów pirotechnicznych mieszanin opóźniających stosowanych w zapalnikach elektrycznych na ich właściwości... ...........71

Jolanta BIEGAŃSKA, Krzysztof BARAŃSKI

Investigations of Flame Retardant Properties of Zinc Borate Accompanying with Huntite and Hydromagnesite in Polymer Composites ...............79

Hüsnügül YILMAZ ATAY, Öykü IÇiN, Buket KURU

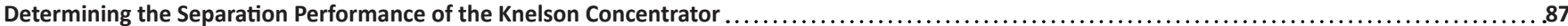

Ozcan ONEY, Selcuk SAMANLI

How Selected Energy Commodity Prices Volatility Impacts Gross Domestic Product (GDP) Fluctuation with Respect to Selected.......................93

Robert RANOSZ, Barbara KOWAL

Wskaźniki rentowności jako miary efektywności gospodarowania w spółkach węglowych w latach $2014-2018$.................................99

Grzegorz GOŁĘBIOWSKI, Elżbieta KRÓLIKOWSKA

A Proposal of Rock Burst Control Measures at the Coalface No. 14064 at the Mining Plant 1, in OKD, A. S. Czech Republic .......................105

Václav ZUBÍČEK, Vlastimil HUDEČEK, Milan KUBICA

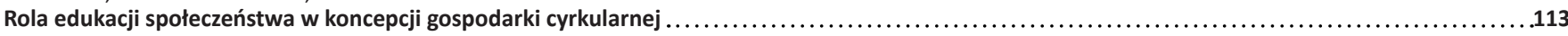

Anna KOWALSKA, Wiktoria SOBCZYK, Kinga KORZEC

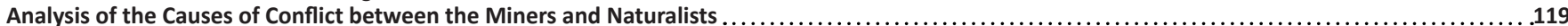

Wiktoria SOBCZYK, Anna KOWALSKA, Eugeniusz Jacek SOBCZYK

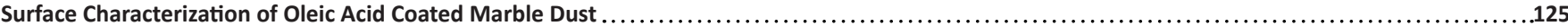

Ercan POLAT, Taki GÜLER, Oktay CELEP, Selçuk AKTÜRK

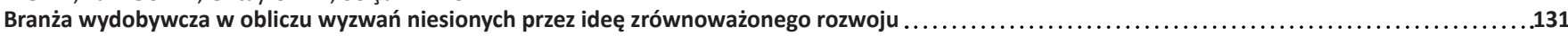

Klaudia BOGUSZ

Perspektywy budowy parku przemysłowo-technologicznego dla mieszkańców Zagłębia Miedziowego $\ldots . \ldots . \ldots 139$

Grzegorz PRZYBYLSKI

Wykorzystanie informacji uzyskiwanych z monitoringu parametrów pracy do wprowadzania zmian technicznych w modernizowanych... .............145

Mirosław LEWICKI, Tomasz KANIEWSKI, Paweł ŚLIWIŃSKI

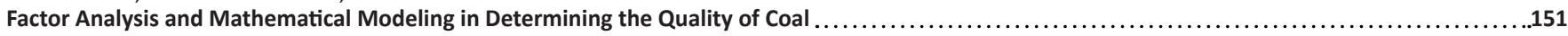

Tomasz NIEDOBA, Paulina PIĘTA, Agnieszka SUROWIAK

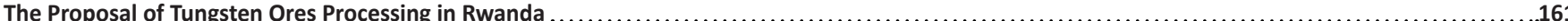

Leader Senga UWAYEZU, Waldemar MIJAt, Tomasz NIEDOBA

Uwagi w sprawie interpretacji zasad wyznaczania zasięgu rozrzutu odłamków skalnych w robotach strzałowych ..............................171

Krzysztof BARAŃSKI, Ryszard MORAWA

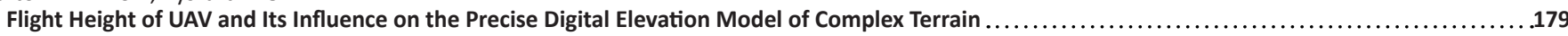

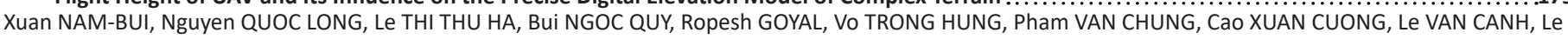

HONG VIET

Probabilistyczny model dyskretnego rozkładu gęstości warstw w łożu osadzarki ............................................187

Stanisław GŁOWIAK

The Use of Multidimensional Exploration Techniques to Assess the Similarity of the Development Level of Energy Markets .......................199

Anna BLUSZCZ, Robert RANOSZ

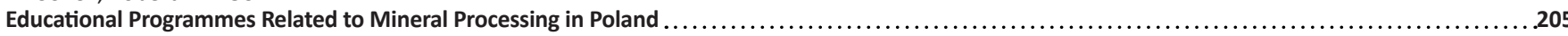

Daniel SARAMAK

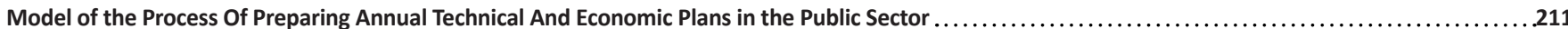

Arkadiusz KUSTRA, Robert RANOSZ, Barbara KOWAL

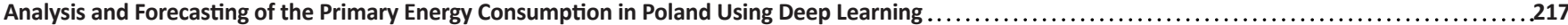

Anna MANOWSKA

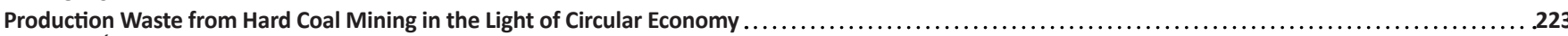

Katarzyna TOBÓR-OSADNIK, Małgorzata WYGANOWSKA, Barbara KOWAL

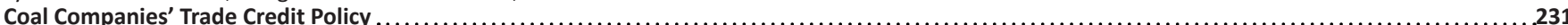

Maria SIERPIŃSKA

Aspects of Motivation and Engagement of Employees in Their Work Based on the Example of Mining Companies .....

Barbara KOWAL, Małgorzata WYGANOWSKA

Strategic Analysis of Selected Factors Shaping the Occupational Health and Safety Culture of Mining Companies in Poland, Part 2 ...............243

Mariusz KAPUSTA, Patrycja BĄK, Marta SUKIENNIK

Conditions for the Innovation Activities of Energy Sector Enterprises Shown on the Example of Mining Companies ..............................249

Robert RANOSZ, Anna BLUSZCZ, Dominik KOWAL

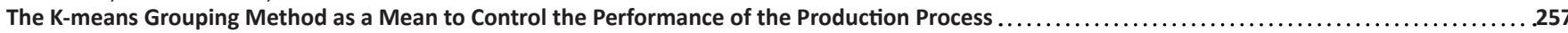

Marek KEุSEK

Zastosowanie metody wartości wypracowanej (EVM) do oceny projektów górniczych - podejście krytyczne - część 1 - założenia metody............265

Adam GETLER, Seweryn TCHÓRZEWSKI

Metody redukcji hałasu w świetle wymagań środowiskowych oraz uregulowań prawnych. ..

Tomasz LEŚNIAK, Arkadiusz KUSTRA 